\title{
Chiefdoms and chieftancies in Fiji. Yesterday and today
}

\section{Simonne Pauwels}

Translator. Nora Scott

\section{(2) OpenEdition Journals}

\section{Electronic version}

URL: http://journals.openedition.org/jso/7336

DOI: $10.4000 /$ jso.7336

ISSN: $1760-7256$

\section{Publisher}

Société des océanistes

\section{Printed version}

Date of publication: 15 December 2015

Number of pages: $189-198$

ISBN: 978-2-85430-126-7

ISSN: 0300-953x

\section{Electronic reference}

Simonne Pauwels, "Chiefdoms and chieftancies in Fiji. Yesterday and today », Journal de la Société des Océanistes [Online], 141 | juillet-décembre 2015, Online since 15 December 2015, connection on 21 December 2020. URL : http://journals.openedition.org/jso/7336 ; DOI : https://doi.org/10.4000/jso. 7336

\section{(C) $\mathbb{D} \Theta \Theta$}

Journal de la société des océanistes est mis à disposition selon les termes de la Licence Creative Commons Attribution - Pas d'Utilisation Commerciale - Pas de Modification 4.0 International. 


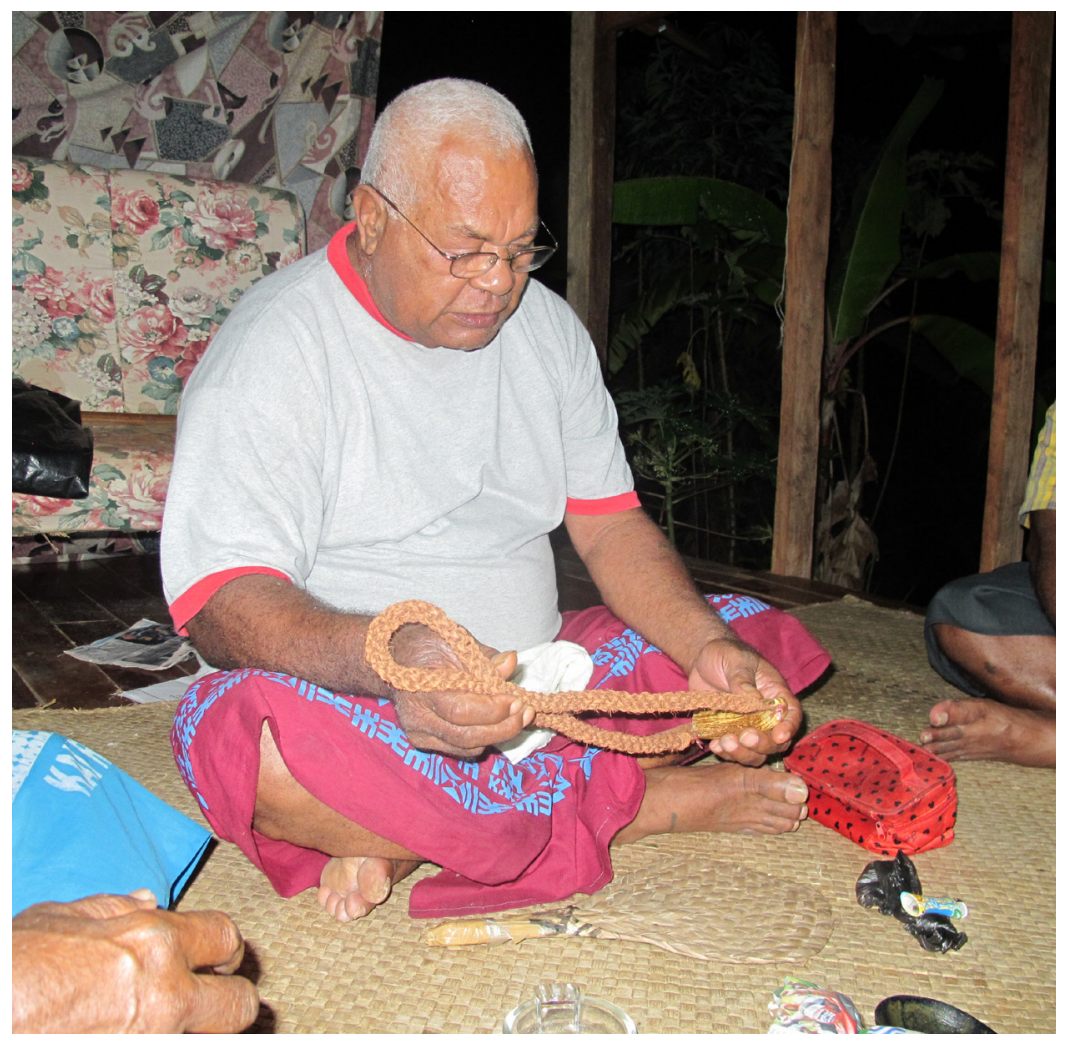

Рното 1. - Tui Korocau receiving a whale's tooth during the first visit in the village of his sister's child, Nakobo, Vanua Levu, Fidji (6/11/2015) (picture of Simonne Pauwels)

Рното 2.- Kava session with the chief, Nakoba Nakobo, Vanua Levu, Fidji $\quad(9 / 11 / 2015)$ (picture of Simonne Pauwels)

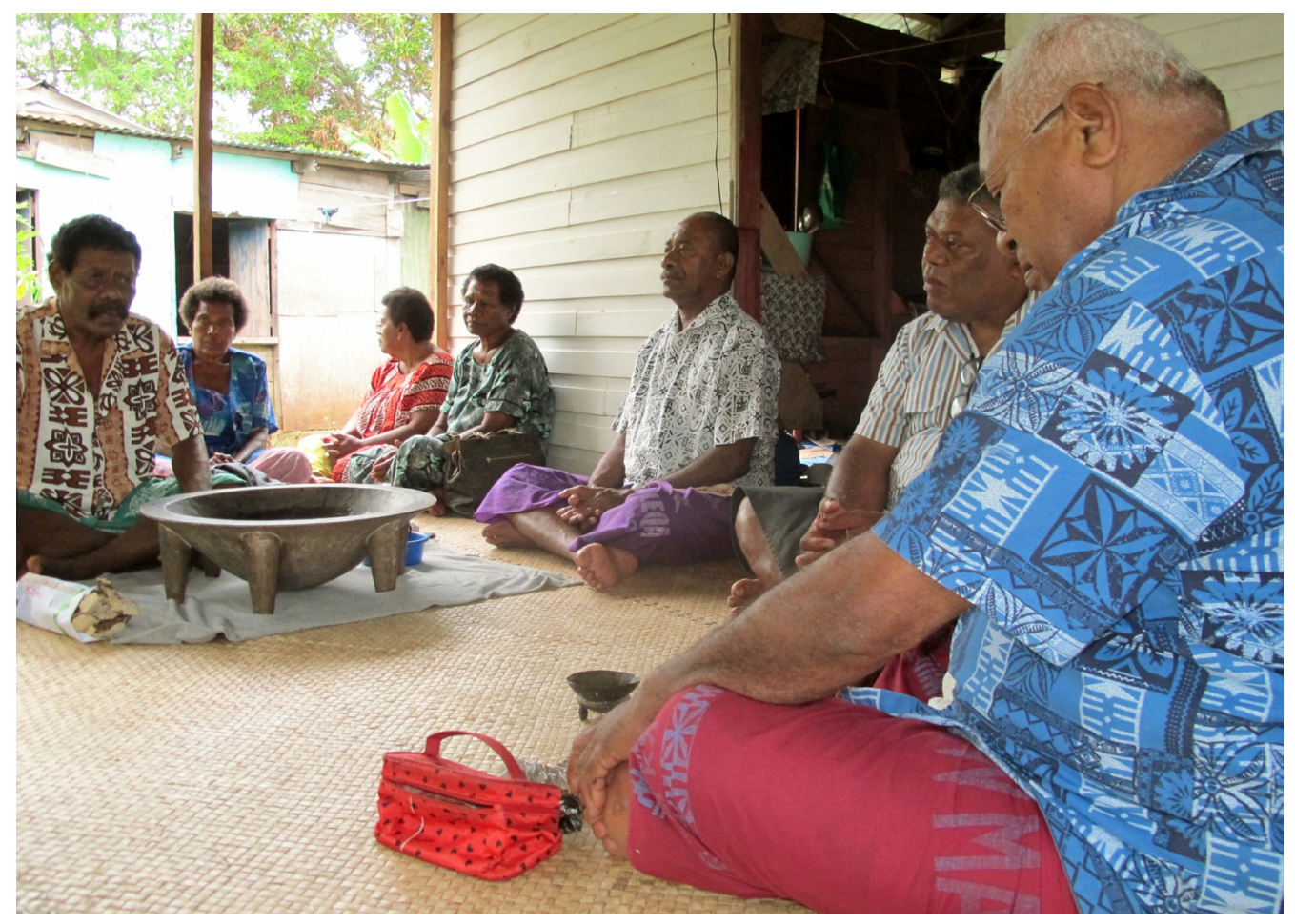

This volume benefited from a support of the Maison Asie-Pacifique (Aix-Marseille Université) for the translation of the introduction and the revision of the English texts by Nora Scott.

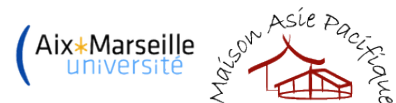




\title{
Chiefdoms and chieftancies in Fiji. Yesterday and today
}

by

\author{
Simonne PAUWELS*
}

One cannot properly speak of Fijian chiefdoms in the singular, so closely is the definition bound up with spatial and temporal configurations as well as with the status of the speakers in Fijian society. There exists nevertheless an idealized version of the chiefdom, transmitted not only by colonial administrators, historians and anthropologists (Roth, Scarr, Geddes) but also by certain contemporary Fijians, often from chiefly families. They see the chief as a condition sine qua non of village well-being within a logic of reciprocal service: the people serve him, who in turn serves the people by redistributing the wealth while ensuring peace and abundance. According to the idealized version, this harmonious state of affairs dates from precolonial times, and was preserved by the colonial powers and the creation of the Great Council of Chiefs (GCC). Today the promise of a return to this state is held out by part of the traditionalist, conservative opposition. The reality is quite different, much more complex and certainly less uniform. This will become clear as the reader goes from one article to the next in the present dossier, traveling through time as well as space, and respecting the status of the speakers.

In the course of a rapid historical overview, this introduction will address two facts that are important for a full understanding of the articles. In the first place, a distinction must be made between the eastern part of Fiji, which was in contact with the Whites from their arrival, and the western part together with the interior of the main island of Viti Levu, apparently less marked by hierarchy but also lacking marketable goods and later, when the planters arrived, already under the yoke of two major chiefdoms, Rewa, and especially Bau. Secondly, there are two contradictory readings of the relationship with the land, depending on whether one is a chief or an "original occupant", itaukei. This two-sided reading has probably always existed. But the dichotomy has grown with colonization, with the overinterpretation of certain rights and duties, but also under the influence of certain English glosses and translations of Fijian concepts. Even today the land register is not complete for all of Fiji and does not satisfy the original occupants; it is a source of sometimes centuries of conflict and fuels a huge number of frustrations among the indigenous populations. ${ }^{1}$ There are a great many works on the history of Fiji that can help understand these facts (Campbell, France, Maude, Reid, Routledge, Sahlins, Scarr, Spurway, Toganivalu, to mention only a few), to which must be added the official documents beginning in the 1850s. Before that date, we must be content with the writings of missionaries (Calvert, Fison, Lyth, Waterhouse, Williams, etc.), which are rich in information to be sure, but sometimes partial, as are those of the voyagers and various beachcombers. ${ }^{2}$ From the outset, anthropologists (Hocart, Hooper, Nayacakalou, Sahlins, Ravuvu: Fijians or working in Fiji) have taken an interest in land registers, central as they are to the society and

1. No article deals with the Indo-Fijians' relation with the land, which would have taken us too far from our topic.

2. A bibliography and data from the sources analyzed can be found in Stéphanie Leclerc-Caffarel's article by in this dossier (pp. 199-222).

NDLR. - Cette introduction est disponible en anglais sur jso.revues.org et sur cairn international/This presentation is avalaible online in English, see jso.revues.org and http://www.cairn.info/revue-journal-de-la-societe-des-oceanistes-2015-2.htm

AMU-CNRS-EHESS, CREdo (UMr 7308), Maison Asie-Pacifique, Marseille, simonne@pacific-credo.fr 
its division into two major groups, turaga and itaukei. If it is impossible to provide a single description and/or definition of "chief", it is even less possible to do so without speaking of his relation to the land. This observation features more or less explicitly in each of the articles in this dossier, including the article on Micronesia, which has been included for purposes of comparison.

\section{Land and the chiefs}

Precolonial society was never homogeneous, even, as it has often been suggested, in the eastern chiefdoms. Regional traditions were varied, the chiefdoms and confederacies war-like, alliances were made and unmade in response to marriages, wars of succession, etc. But the final decades before the cession to the British Crown were the theater of two major events: the Westerners' discovery of two lucrative commodities, sandalwood (1802) and bêches-de-mer, or sea cucumbers (1820), and the arrival of Christian missionaries (1835), first from the Methodist Church and three years later from the Catholic. These interlopers provided the chiefs with both the possibility and the desire to assume growing power over the people, subjecting them to forced labor at will and progressively alienating their lands, over which they still lacked authority. The chiefs claimed they were punishing their disloyal "subjects", ${ }^{3}$ but in in fact they saw this as a means of gaining possession of the capital they needed to procure Western goods. Even if they were often a source of conflict, religion and trade shared the same need for stability, and in the mid $19^{\text {th }}$ century saw a solution in the construction of an all-encompassing unity such as a kingdom or, later, a colonial State (Bayliss-Smith et al., 1988; Clammer, 1976; Howard, 1991; Ryle, 2010).

When the first contacts with Westerners occurred (1800), it was the chiefs and not the least among them, who built up a relationship with these whalers, travelers, castaways and other beachcombers from the United States, Spain (and Manilla), or from the British colony in Australia (Leclerc-Caffarel in this dossier, pp. 199222). These initial exchanges of objects were often the starting point for true commercial exchanges: sandalwood and bêches-de-mer for guns, cachalot teeth for boats, for example. The Whitemen's weapons and those who knew how to use them were pressed into the service of trade, itself dependent on labor to exploit the sandalwood and bêchesde-mer. In some regions, the presence of goods coveted by the Whites created local conflicts and fueled an armed re-definition of power relations between chiefs, to the detriment of the people, now synonymous with manpower. There is no doubt, therefore, that the labor the commonors provided their chief - by cultivating the land, building houses, fishing, and so on - known as lala (Leclerc-Carrarel), grew more intense and even changed in nature. The relation binding the chiefs to their people underwent transformations that were set down in writing in 1872, as we will see, by a number of chiefs in consultation with each other. These transformations would later, after the Cession, be discussed at length in the early meetings of the councils of chiefs.

Previously, between 1815 and 1825, in the chiefdom of Bau, as Leclerc-Caffarel tells it, Chief Naulivou managed to extend his influence as far as the central part of the archipelago (Koro Sea) as well as to the little island of Viwa, strategically located between Verata and Bau. He also collected tribute on the north coast of Viti Levu, the south coast of Vanua Levu and in the central and eastern islands (Lomaiviti and Lau, respectively). At the end of his reign (in 1829), Rewa was the only chiefdom that could claim equality with Bau. The role played by Charles Savage ${ }^{4}$ at the beginning of this rise to power is meticulously analyzed in the article already mentioned. Naulivou's successor made every effort to make allies rather than enemies of the Westerners, and to turn their potentially destructive power to his advantage. His son, Cakobau, converted to the Methodist Church in 1854 in order to secure the help of the King of Tonga and of Ma'afu ${ }^{5}$ in defeating the chiefdom of Rewa. Following his victory, he became the ally par excellence of the merchants, consuls and EuroAmerican advisors gathered in the capital, Levuka, as well as principal ally of the missionaries. His political career would thenceforth be all mapped out (see below).

With the arrival of the missionaries in 1835 , as later with that of Ma'afu, son of one of the three high Togan chiefs and potentional successor, the Lau, until then confined to the island of Lakeba and its zone of influence, which extended from the Island of Cicia in the north to that of Ono, at the southern tip of the archipelago, were subjected to major changes. Under the guise of what is commonly called "the war of Christianity", valu ni lotu, but which was actually a war of conversion the territory was enlarged to the islands of Vanua Balavu and Moala and to their dependencies, at

3. For instance, in the 1850s, Golea Lalabalavu, high chief of Cakaudrove, sold the island of Kanacea, north of the Lau islands, and moved its population to the island of Taveuni after it had supported a Tongan warrior in a war against the chiefdom.

4. Charles Savage was a castaway, a clever strategist and fine marksman who lived alongside Naulivou until 1813.

5. For further historical details and a close analysis of the issues through the life of the Tongan chief Ma'afu, who played a major role after having taken, in 1869, the title of Tui Lau that had been created for him and managed to unify the chiefdoms of Lakeba and Vanua Balavu as Lau chiefdoms, see the work of Spurway. 


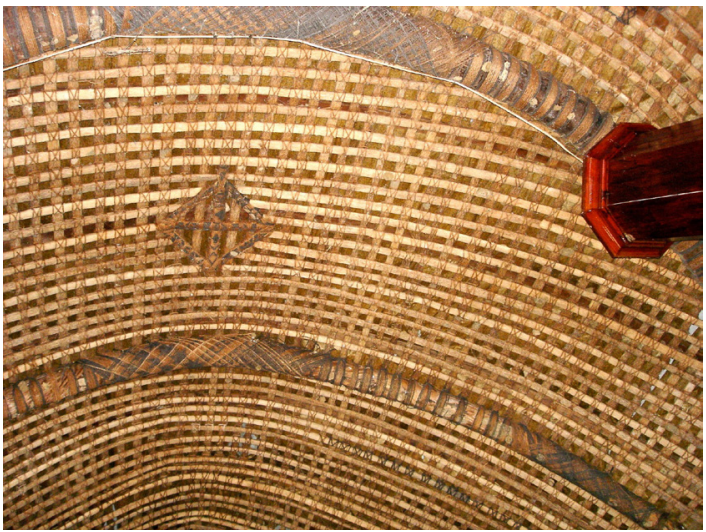

Picture 3. - Roof and ridgepole of the chiefly church of Tubou (Lakeba, Lau) (@ S. Pauwels, 2007)

the expense of the chiefdoms of Cakaudrove and Bau. Ma'afu's growing influence, and then his takeover with the tacit consent and support of the missionaries and that of his relative, the King of Tonga - who made him governor of the Tongans in Fiji -, left a profound mark on the archipelago. The system of land tenure, at the very heart of the concepts of chiefdom and even more of chief, as we will see in all the articles, was left in a shambles, traces of which subsist today. The land was divided up between Fijians and Tongans, of whom there were many in the east of Fiji, so as to maximize tax revenues; but, another exception in Fiji, Ma'afu decided that, in the Lau group, unused land could not be alienated, merely rented out - for his own profit and not that of the traditional owners. In 1869, when the King of Tonga withdrew from Fijian affairs, the missionaries and European advisors created the new title of Tui Lau especially for Ma'afu so that he might become a Fijian "chief" and remain in the area. Tui Nayau, restricted to Lakeba and its zone of influence, became a secondary title.

While still under the influence of Ma'afu, the balance of power between chiefdoms shifted. Bua, Cakaudrove and Lau formed a confederacy with Ma'afu at its head. The rivalry between Ma'afu and Cakobau, who with the support of the missionaries, the merchants of Levuka and the planters of Viti Levu, conducted himself as though he were the paramount chief of of all the Fiji Islands, reached its height. Tensions were running so high that Western observers feared a war that would threaten their businesses and plantations.

In 1874, in response to pressure from settlers of all kinds and from Thurston, ${ }^{6}$ the then honorary British Consul, a Fijian kingdom was created which brought together, for better or for worse, the powerful chiefdoms of the time. Cakobau was named king, with the title of Tui Viti, and Ma'afu became viceroy. The legislative assembly included both Fijians and settlers.

A constitution was drawn up. In a decision that was often criticized, an important place was obviously given to the status of the chiefs, making a definitive distinction between "ruling chiefs" and subordinate chiefs, or "vassals". But if we concentrate on the notion of chief in relation to the land, the import of the following phrase is clear:

"The lands of Fiji are vested in the ruling chiefs, and occupied by their subordinate chiefs (or vassals) and people in consideration for past, present, and future services." And further on: "The ruling chief has the right, and also the power, to remove at pleasure any sub-chief or people from the lands they occupy. " (Fison, 1903 : 349)

The "ruling chiefs" were principally Cakobau, Tui Bua, Tui Lau, Tui Macuata, Roko Tui Dreketi from Rewa and Tui Cakau from Cakaudrove. The nature of their new authority entailed that the subordinate chiefs in their respective domains were obliged to give their allegiance. No doubt this paragraph was written jointly by chiefs and settlers, who sought to establish the means of developing an economically profitable kingdom, even if their interests of necessity turned out to be in competition. The choice of the five ministerial portfolios is noteworthy: Chief Secretariat and Ministries of Trade and Commerce, Lands and Works, Finance and Native Affairs. These alone prove that the underlying aim was to simplify land tenure, to manage the presence of indigenous peoples under the authority of the chiefs and in the interest of trade and the plantations. The kingdom was a fragile construction. Very quickly the eastern chiefs were prepared to break with Cakobau, who they felt did not deserve the position of king and had usurped the rights he claimed on the interior and western part of Viti Levu and on the Yasawa group.

The idea of cession to the United Kingdom again came up, despite its initial rejection in 1862. ' In the meantime, Thurston, Cakobau's Prime Minister and a fervent opponent of the presence of Ma'afu in Fiji, drew up, with the agreement of the king, a document containing 19 articles (Spurway; 2015: 397), which he delivered to the British government in 1873 . The articles detailed the future titles and salaries for Cakobau as well as for other chiefs. But more interesting still is that they also stipulated that:

6. Thurston, a British citizen who had joined a botanical expedition in 1864, was shipwrecked off the shore of Samoa. A few months later he arrived in Fiji and in 1969 was made consul of Fiji and Tonga.

7. For further details on this first offer of cession and a glimpse of the tense relations between Pritchard, Ma'afu and the missionaries, see E.A. Brown (1973), Samson (1998), Spurway (2015), Thornley (2002). 


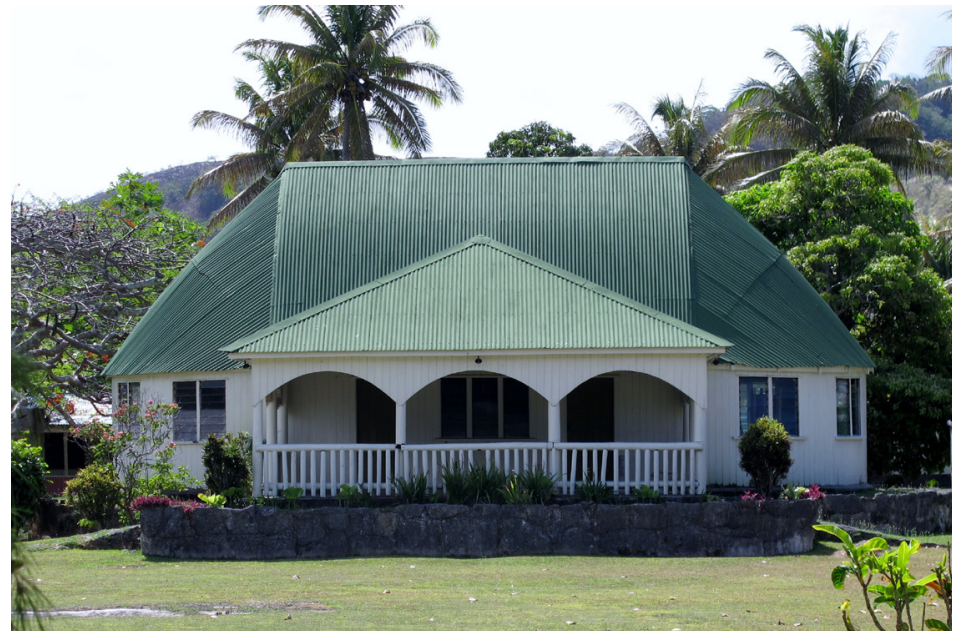

Рното 4. - Residence of the Tui Lau in Vanuabalavu, empty till the installation of the next Tui Lau, 24/10/2015 (C S. Pauwels)
Looking at the two stages constitution of the Kingdom then proposal of cession - we see that, when the chiefs talk about themselves, they evoke their respective ranking, the lands they claim to "own" and the people at their service. Unfortunately it is impossible to know the word or the Fijian notion the chiefs accepted to be translated as "owner of the land". 8 It is nevertheless certain that an itaukei ni qele, or "original occupant of the land" ( $c f$. all articles in this dossier), would have preferred the expression "responsible for the land", in other words responsible for its use

"the Fijian chiefs were to retain all existing private rights, real and personal" (article 15),

and then that:

" the ruling chief of every tribe [was] to be recognised as the owner of the lands of his tribe, and guardian of their rights and interests " (Spurway, 2015: 398)

These conditions implying that the Fijians continued to own their lands were the reason the Colonial Office rejected them. Queen Victoria personally spoke out to say that the offer of Cession was acceptable, but only if it was unconditional with regard to land (Spurway, 2015: 415). This in no way meant the Crown was unaware that, for the Fijian chiefs, land was the crux of their authority. But for the Crown, all lands of a colony must be at the Crown's disposal. In Fiji, a proper balance between the two positions was found: the Crown claimed for itself the right to first regulate landuse, then leaving the bulk of the lands in the hands of the chiefs and their people. Even before annexation, all observers and advisors (Pritchard, Swanston, Thurston, Goodenough, Robinson, etc.), while favoring different tendencies, had noted the peculiar (for Westerners) nature of the Fijian land-holding system; they also bore in mind that much of the land was already in the hands of European or American self-proclaimed owners, which it would be unwise to expropriate in a colony of planters providing they held "legitimate" title. and its fertitily in the service of the well-being of the chief and of his people. The chief would define himself by his belonging to a particular land, like all members of his social unit from the time they settled there.

In any event, the offer, as it was formulated, was deemed unacceptable by the Crown, not because it did not take into account the rights of the itaukei but because it failed to give the Crown what it deemed its rightfull due.

The Deed of Cession was signed in October 1874 (text available at: www.usp.ac.fj). Paragraph 4 stipulates that the proprietorship of

" all lands not shown to be now alienated so as to have become bona fide the property of Europeans or other foreigners or not now in the actual use or occupation of some Chief or tribe or not actually required for the probable future support and maintenance of some chief or tribe shall be and is hereby declared to be vested in Her said Majesty..."

Paragraph 7 adds that all claims to title by whomsoever shall in due course be investigated and adjusted.

Thirteen chiefs ${ }^{9}$ signed the document, and the Colonial Office, thinking to build it's governance on a traditional form of Fijian rule, divided the country into twelve provinces, each governed by a Roko Tui, who had been identified as the highest chief in the respective confederacy (matanitu) (Nayacakalou, 1975: 83). The Colonial Office formally installed them. Interestingly, the Roko Tui wore two hats from the outset: deputy to the governor, and hereditary and customary authority in their chiefdom. The ruling chiefs

8. To my knowledge there is no written version in Fijian of the offer of cession. Alternatively, the Deed of Cession (Geraghty, 2003) exists in Fijian together with an explanation in the same language designed for the main signataries; it was stumbled on in 2012 and is now in the National Archives of Fiji.

9. Of whom two for the chiefdom of Macuata, which for decades had been embroiled in a fratricidal war, often stoked by Ma'afu, who invoed the protection of the Methodists. Absent were the chiefs of the interior of Viti Levu and western Fiji, including the Yasawas (see Cayrol in this dossier, pp. 223-238). 
and the subordinate chiefs would meet annually in a Council of Chiefs (Bosevakaturaga), the ancestor of the Great Council of Chiefs (see Cretton, this dossier, pp. 267-282), in order to advise the Colonial Office, to receive directives and to transmit them in their local provincecum-chiefdom. The chiefdoms were ranked once and for all, to the detriment of underrepresented regions or those represented by chiefs whom the inhabitants did not recognize as representing them.

The Deed of Cession also promised to look into the ownership of all lands, including those in indigenous hands, without going into further detail. But in his journal (cited by Spurway, 2015: 430, note 63), Thurston, now Colonial Secretary, clearly echoed the prevailing state of mind at the time of signature:

"The chief of every qali [was] to be acknowledged and recognised as owner, absolute, of the lands of the qali and guardian of the interests and rights of the people. " (Thurston, n.d.)

Given that Thurston read Fijian events through the lense of Bau, we can translate qali by "territory of subjected persons", as in the expression qali vaka Bau, "subjected territory of Bau". It is therefore the territory that is subjected and not the chief. The expression is not used in all parts of Fiji, but its utilization here shows how, from the outset, the colonial government, aware of the socio-political diversity of its colony, created uniformity through the imposition of a neo-traditional order modeled on the chiefdom of Bau: the consuls and other British advisors, the settlers of Levuka, the planters and the missionaries had already established privileged relations with this chiefdom and had contributed to its rising power. The other eastern chiefdoms, such as Rewa, Bua, Cakaudrove or Lau, saw their dissimilarities denied, but the West and the interior of Viti Levu, which were even more different, were brought to heel (see Cayrol, this volume, pp. 223-238) and forced into the mold of uniformity. This produced three large matanitu (confederacies: Burebasaga, Kubuna and Tovata, which included the chiefdoms of Cakaudrove and Lau). Western Fiji and the interior of the main island of Viti Levu in time became the provinces of $\mathrm{Ra}$ and $\mathrm{Ba}$, and were divided between Burebasaga and Kubuna instead of being joined into a fourth matanitu with its own identity.

As promised in the Deed of Cession, one of the first concerns of the colonial government was to understand the system of land tenure

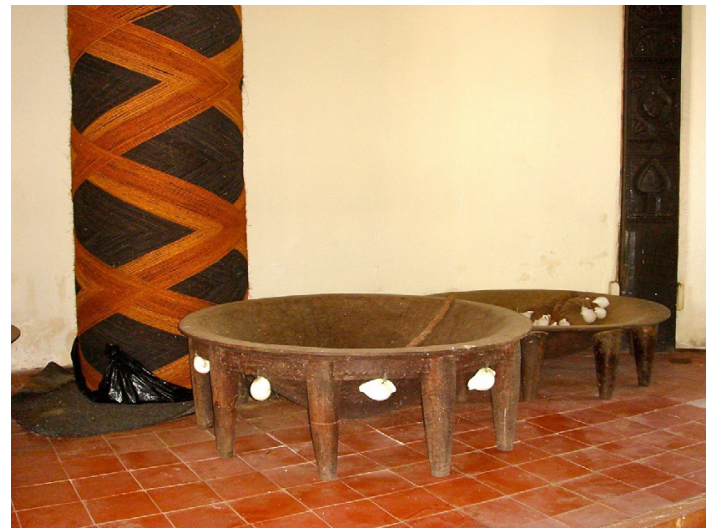

Рното 5. - Chiefly tanoa in the residence of the Tui Nayau (Tubou, Lakeba), 2007 (C S. Pauwels)

(France: 1969). The Council of Chiefs was asked to report on the subject, but confronted by the diversity of the system and the personal interests at stake, they were unable to reach agreement. Meanwhile, Gordon had the property deeds of the settlers verified, but the situation of the itaukei went unchanged. In the end, Lorimer Fison ${ }^{10}$ set out to make a complete inventory. Concerned with restoring their landrights to the itaukei, he gave a milestone speech, ${ }^{11}$ laying out definitions that were rapidly applied. If he clearly stated that rules for the succession of chiefs or their power varied from one part of the country to another, he nevertheless explained the social units as being modeled on those of Bau. Taking into consideration the administration's desire to have a single system of land tenure throughout the colony, he presented the mataqali as the proprietor of the land.

The consequences of this speech can be seen in Fijian society to this day. The very definition of mataqali, which in fact had several, was uniformized. In certain regions the smaller social units, such as the tokatoka, were forced to fit themselves into the mataqali of which they were a part, thus abandoning their land rights. In others, the mataqali governed by chiefs that the colonial administration deemed to have insufficient lands were given more. ${ }^{12}$ The varied interests of the settlers as well as those of the chiefs coincided: on the one hand, the chiefs were well aware that their future depended on the power they could acquire or keep over the lands so as to amplify their titles, while on the other hand, the colonial government wanted to achieve a uniform governance by a moderately expensive and peaceful "indirect rule" of the indigenous

10. Methodist missionary, anthropologist, and friend and informant of Lewis H. Morgan, he gave him information on the Fijian (and Tongan) kinship systems, which Morgan added to the third part of his Systems of Consanguinity and Affinity (1871).

11. The speech was given in 1880 in front of the future investigators of the Land Claims Commission, but was not published until 1903, at the time of the second campaign of the Land Claims Commission.

12. To better understand the lack of land in these chiefly families, see Eräsaari in this dossier. 
society, isolating it from that of the settlers and from the developing money economy (Walter, 1978). Uniformization would continue to be an ongoing preoccupation in Fiji!

Fison had learned from Morgan that Fijian society had attained the stage of development in which land ownership was collective and inalienable, even by the chiefs. His discourse therefore intended to prove this and to convince Governor Gordon that it was so. Here we see that the aim of the demonstration was twofold: to attest the inalienability of the land and to show that, if the chief was a "Lord" he was not a "Landlord" (Fison: 345). Fison began by presenting two points of view inevitably encountered by an inspector for the Land Claims Commission: that of the chiefs claiming to be the "owners of the land", and that of the itaukei, translated as "proprietors of the soil" and claiming to be the sole proprietors. The itanke $i$ were reputed to be the original occupants of a land; the chiefs were latecomers from outside whose exceptional physical qualities and ability to command prompted the itaukei to invite them to become their chief (see Sahlins' Stranger-King, 1981). Fison does not question these translations in his text, but they were clearly not fortuitous. "Land" is vanua in Fijian, and "soil" is qele. Vanua can designate the land, the country but also its inhabitants, its forest, sea, shore, a plot of land, a neighborhood, a village, a region, a chiefdom, etc. Qele has only one meaning: it is the soil in which one plants or on which one builds. For Fison, both statements were true and at the same time both were false. He considered that there had been an evolution: the land had belonged to the itaukei and now the chiefs had taken it over. But at the time he was writing, he no longer made a distinction between "land" and "soil".

The mataqali had thus become the social unit to which a land belonged: it often included persons who traced themselves back to a common ancestor, through bloodlines or through a bond of simulteous migration, etc. ${ }^{13}$ The mataqali in a chiefdom contained different functions: priests, warriors, cultivators, distributors of offerings, fishermen, sailors, chief-makers, etc. One person might preferably cultivate the lands of his own mataqali, but he could also ask the chief of another mataqali to be allowed to cultivate that chief's lands providing he brought him the first fruits of his labors. Theoretically this request was limited to village lands. Someone who wanted to clear a piece of land proceded in the same manner, and the usufruct thus obtained became hereditary. But if, as we have seen, not all chiefs were landowners, other categories are still not. Fison gives the example of the kai tani, strangers, fugitives, prisoners of war and so on. A stranger remains a stranger, but if he possesses an exceptional quality (a man of peace or a man of war), the chief will give him his daughter in marriage together with a piece of land. His son in turn will become a vasu, "a sister's child", and taukei vulagi, "a holder of stranger's land", until the memory of this disappears, but, Fison adds, it never does.

Next come the kaisi, sometimes translated as "slaves" in the literature, who are said to have no soul, no ancestors, no gods. In reality these are descendants of fatherless people, or "husbandsmen". ${ }^{14}$ As they have no land, they work the land for others. Use of this term is practically forbidden in Fiji; it is insulting, even if, locally, whole villages are seen to belong to this category.

For instance, migrants who were itaukei in their own village and who, following a quarrel or, formerly, driven out by war, settle in another village cannot become kaisi: "they will always have ancestors". But since they are working someone else's land, it can be taken from them at any time. Villages that, in wartime, submitted to a chief clearly remain proprietors of their land, even if they paid a tribute by providing military services and offering food in peacetime.

Did conquest affect the ownership of a land, then, perhaps the basis of proprietorship for the "conquering" chiefs? Here, too, the ethnographic material says "no". Conquest concerned fruits of the land but not the land itself. Likewise, the title carried by the chief of a conquered mataqali remains alive as long the mataqali exists, as long as it still has living members. It is the title that, beginning with the first occupant, binds the members of a mataqali to it inalienably.

All this obviously remains the viewpoint of the itaukei, who, on the other hand, do not deny they owe services and offerings to their chief, and will say that they perform these willing, but in no way as serfs or tenants. The chief is their "Lord" but not their "Landlord"; if he is allowed to take the fruits of the land, he may not take the land itself, qele.

At the time of the first contacts, it would seem that the chiefly point of view was that they were masters of the fruits of the land (and of the sea). Having the right to the sandalwood and the bêches-de-mer, they also had the right to the labor of the inhabitants of the chiefdom, in the form of lala. This viewpoint obviously suited the Europeans, who, before the establishment of the official colony, had shown little concern for the fate of the people, leaving it to the Fijian chiefs to increase the services, which gradually became a form of forced labor. What at the outset was a reciprocal relationship between a chief and his people became a relationship between three parties,

13. For further reasons to come together in a mataqali, see Eräsaari and Cayrol, this dossier.

14. Not having a father, they do not have access to the land of their father's mataqal. They can only cultivate the land of their wife's mataqali as dependents. 


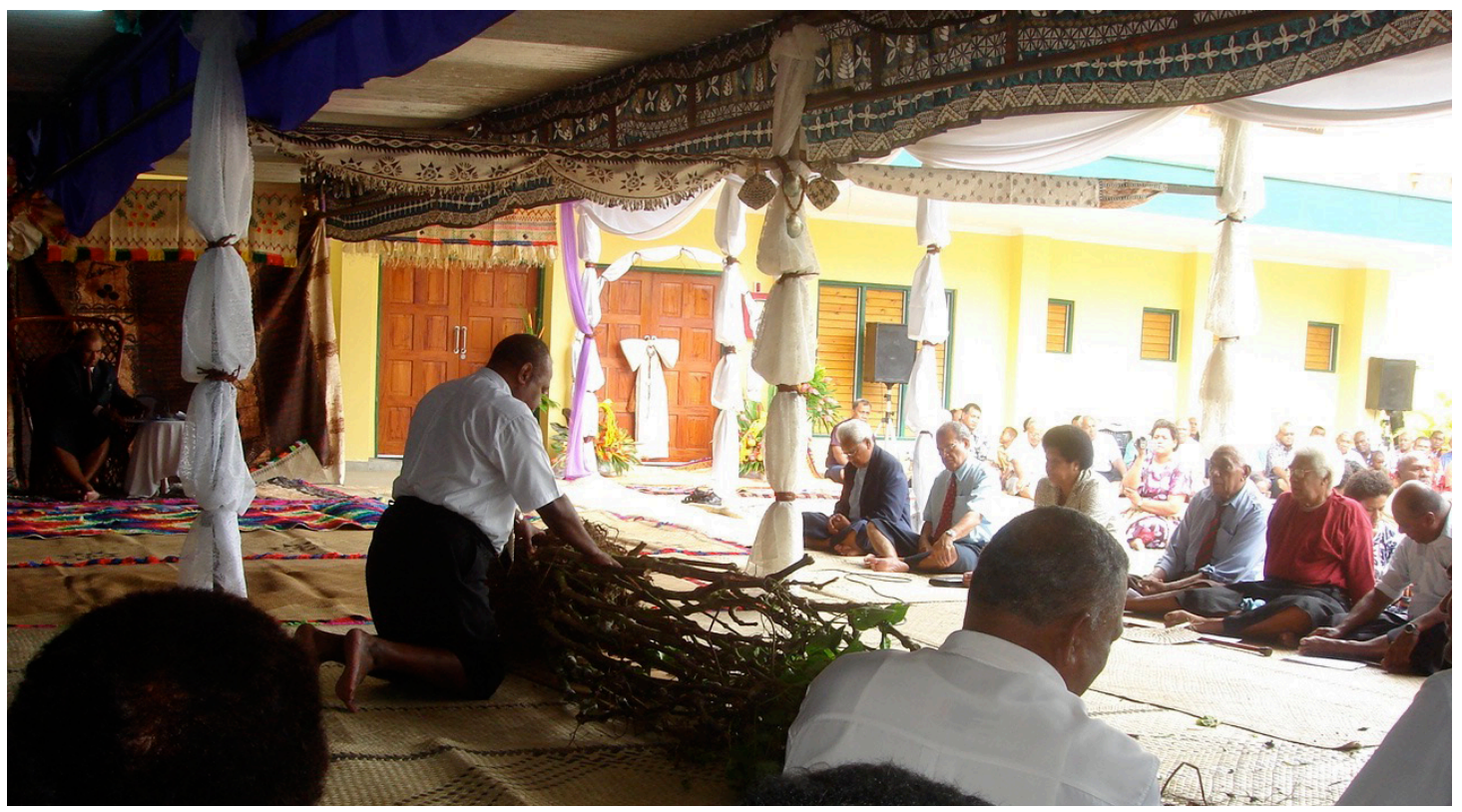

Рното 6. -Kava root offered to the acting chief during the opening rituals of the new Lauan Provincial offices in Suva $(11 / 12 / 2008$, (C) S. Pauwels)

in which the goods of the Whites and the monetary economy came to play an important part. The services rendered to the chiefs, such as offerings to the earthly representatives of the ancestral gods, increased as the chiefs lost their divine quality. As one of Hocart's informants put it:

"[...] it is not the right of the chiefs [turaga] to oppress the people. Some people imagine they are chiefs by themselves and forget that but for the landmen [itaukei], they would not be chiefs. " (Hocart, 1929: 98)

Insofar as the chief was installed with a ritual, veibuli, and not by the administration, his divine character would be indisputable for the people, who "caused him to be born (chief)", buli. Here is how, in 2010, one of my Lakeba informants, who was not from the chiefly line, described the highpoint of the very complex installation ceremony:

"The chief of the itaukei, after having given a kava root [symbol of the land], ties a piece of tapa [another symbol of the land] around the arm of the future chief, saying: 'I give you the entire responsibility (lewa taucoko) over the "land" (vanua), I also give you responsibility and authority over the "people" (lewenivanua).' Then the chief speaks and says: 'I give you back the soil (qele) so that you may plant and cultivate for me." "

I believe the double sense of "land", for which the Fijian language uses vanua and qele, escaped many people. Fison sensed this, as he showed in his translations in which he used "land" and "soil"; the chiefs played on the double meaning when they sold lands to the Whites and then transferred sovereignty to the British. They could choose another chief, give him responsibility for the lands of Fiji, but in no case could they sell the land, for, even if they were chiefs, the soil, qele, had to be cultivated so as to serve them and provide them with offerings for the gods.

The will, set down in the Deed of Cession $\$ 7(3)$, that: "all claims to title to land by whomsoever preferred [...] whether on the part of the said Tui Viti and other high chiefs or of persons now holding office under them or any of them shall in due course be fully investigated and equitably adjusted", led, insofar as indigenous lands were concerned $(87 \%$ of the total), to the creation of the Land Claims Commission (1880, conjointly with the allocution by Fison), and later, in 1940, to the Native Land Trust Board (today Itaukei Land Trust Board). Several campagnes to register lands sufficed neither to finish the work nor to resolve incessant conflicts, often stemming from the dichotomies between vanua and qele, and between turaga and itaukei.

\section{From first contact to analysis of chiefdoms and chieftaincies...}

This dossier ${ }^{15}$ contains five articles, which we have chosen to present in chronological order.

15. The Journal de la Société des Océanistes has never devoted an issue to Fiji and only rarely articles, with the exception of an article touching closely on the subject of this dossier, entitled: "Une noblesse sous contrôle. Le pouvoir coutumier vu de Rewa (Fidji Est)", by Émilie Nolet (JSO 133), and a few recent articles touching indirectly on Fiji, such as "Phosphate 
The first deals with the first half of the $19^{\text {th }}$ century, the time of the first contacts with Whites. The next two analyze chieftaincy or the concept of chief in contemporary Fijian societies: one in the western part and the other in the eastern part of the main island, Viti Levu. Then an article on the position of chiefdoms in Micronesia shows that the relation of chiefs to the land as found in Fiji is not an isolated case but part of a much broader set of cultural values. The final article is a reflection on the chief or leader, once again in Fiji, as a politician in a globalized world.

Stéphanie Leclerc-Caffarel (pp. 199-222) discusses the different ways chiefs managed the incursion of Europeans in the first half of the $19^{\text {th }}$ century. She shows how what began with reciprocal exchanges of valuables turned into commercial exchanges without completely integrating the white partners in Fijian society. On the other hand, the introduction and acquisition of firearms allowed certain chiefs to extend their zone of influence and authority. In parallel, the Europeans and Americans, with the help of the chief of Bau, set up their first colonial capital on the island of Ovalau. Importantly, the plantations made their appearance, and land acquired commercial value. But the author also shows how shifting the balance between the chiefdoms had been even before the arrival of the Whites and how the hierarchy among chiefdoms became set after the shock of colonization.

Françoise Cayrol's article (pp. 223-238) talks precisely about the upheaval caused by colonization in the center of Viti Levu, the region over which Cakobau claimed authority but which was forced to cope with new forms of hierarchy. Starting from a large gathering in the important region of Nalawa at the turn of the present millennium, the author explores the symbolism the inhabitants of Nasau district attach to an ancient site that draws together at the same time their past, their spirits, their wars, the arrival of Christianity and their present. It is unusual to see such a historical reconstruction, particularly in this part of Fiji. Local narratives and rituals are presented as ways of integrating outsiders, from Ba, Viwa, Tonga, India and Europe, without actually making them people of Nalawa since the people of Nalawa do not recognize themselves in the present-day state of Fiji. Proof of this are the events that unfolded in the region between July and September 2015, and wound up in court. Charges of attempted sedition, including against the chief of Nalawa, were brought. The plan was apparently to make $\mathrm{Ra}$ an autonomous, Christian territory. The affair resonated with the expectations surrounding the passage to $\mathrm{Y} 2 \mathrm{~K}$, but also with the lack of inclusion, and thus of the representativity of this part of Vivi Levu, largely left out of the recent spate of economic development.

Matti Eräsaari's article (pp. 241-264) stems from research in the eastern Fijian chiefdom of Verata. Several contemporary changes are presented: in the way of being a chief, in social relations and in exchanges. The dichotomy often attested in the ethnography of Fiji between people of the land (itaukei and hosts) and people of the sea (vulagi and guests) has collapsed owing to the political changes during colonial and postcolonial times as well as to the conflicts typical of multi-ethnic nations. Today, people in this chiefdom no longer use the term vulagi for landless people coming from the sea, such as the chiefs and their families. Instead, the term is used for all allochthonous Fijians and in particular the IndoFijian population. All autochthonous people are therefore considered to be itaukei. This goes in the sense of the recent classification imposed by the State, which designates the indigenous populations as itaukei, while reserving the term "Fijian" for anyone who has this nationality. In Verata, a myth tracing all itaukei to a set of common ancestors is gaining ground. This myth sprang up with the introduction of Indian populations and the ethnic separation brought in by the colonial power; the phenomenon has had a spurt of growth in Fiji as the result of the last decade of political changes in a still-multiethnic State (see Cretton, pp. 267-282).

Matti Eräsaari conducts a subtle analysis of how the common origin attributed to the members of Naloto village renders both persons and objects "classless": there are no longer people of the sea and people of the land, there are now only itaukei. The cachalot tooth, which was highly valued because it came from outside, has become the symbol of indigenousness. Fish, a symbol of the sea, have all but disappeared from exchanges. And the chiefs are no longer installed, but have been replaced by "leaders" chosen in elections for which few line up to run.

Peterson's article is the only one that does not deal with Fiji. Casting his net further abroad, he shows not only that Micronesian and Polynesian societies (including eastern Fiji) share a cultural history that is often forgotten, and but also how Micronesians give their chiefs a place that could inspire the other societies. The first point Peterson cites as being common to these societies was addressed in this introduction and is present in all the other articles: it is the indissoluble bond

mining and the relocation of the Banabans to northern Fiji in 1945: Lessons for climate change-forced displacemen" by Julia B. Edwards (JSO 138-139) or "Le groupe du Fer de Lance mélanésien face à ses défis" by Nathalie Mrgudovic (JSO 140). Other, earlier, articles have dealt directly with Fiji (see https://jso.revues.org/). We hope this special dossier, and this issue, which also present other subjects on Fiji, will stimulate new articles on this fascinating country. 
between the chiefs, the land and the natural and supernatural worlds, sources of mana. The second point, also mentioned in the other articles, is the reciprocal exchange of gifts between chiefs and the people. Clearly these constants do not prevent the existence of major differences, or varying expressions of the struggles for the position of chief. In Micronesia, the separation between two forms of power - war chiefs and chiefs whose authority is based on genealogical ties with ancestor figures - allows the organization of present-day society to achieve a state of equilibrium.

After an enlightening excursus through Western philosophical ideas concerning the relation with the land, and the nature of authority and ownership through working the land, Peterson goes on to establish the parallel with the philosophy of Micronesian societies, in which the reader will also recognize the societies of Fiji. One inversion, though: there where Micronesian chiefs have authority on the land because they were the first to arrive and therefore become chiefs, the Fijians give this authority to their chiefs because they installed them as chiefs when they finally arrived.

Lastly, Glenn Petersen (pp. 255-266) disagrees with outside researchers and with certain members of the societies concerned, claiming that government institutions including chiefs are incompatible with democracy. He maintains that not to take account of the many genealogical manipulations after the installation of a chief is tantamount to failing to see the degree to which the choice, which demands cohesion, is guided by the concern to pick the person capable of exercizing authority. He argues for an analysis that does not oppose "tradition" and "democracy" but focuses on the tensions between the different values and those who represent them.

This is the burden of Viviane Cretton's article (pp. 267-282), which closes this dossier. She starts from the heterogeneous character of the Fijian chiefs and other legitimate leaders, or at least legitimate during the coup d'Etat in 2000. She also analyses the efficacy of the symbolic transactions carried out during the resolution of this conflict. Like Petersen, she criticises the analysis of tradition or of chiefs as obstacles to development, the economy, modernity or democracy.

Having dealt with the concept of "chief" as a plural situated category, Viviane Cretton uses the taking of more than thirty Fijian and Indo-Fijian members of parliament hostage in the 2000 coup d'Etat to show that the dissension between eastern and western Fiji cannot be explained uniquely as survivals of a colonial or even a pre-colonial past. The discontent is inseparable from the economic situation even if it has been historically constructed. During the hostage crisis, the chiefs of the western regions demanded the creation of a fourth matanitu, arguing that the economic activity of the country was concentrated in their part of the country. A testament to the importance of chiefs if such were needed; during the nearly two months of their sequestration, the members of the GCC fulfilled their function of protector in times of crisis, recalling by means of numerous exchanges of tabua, "cachalot teeth", the most valuable and symbolically loaded object, the values of Fijian society: respect and humility.

Finally, the article uses the trajectories of a succession of leaders to show that, if pluralism and complexity are inherent to the figure of the chief in Fiji, polyphony and shading are constitutive of the local and situated representations of mana. Cretton's analysis shows the full complexity of the new configuration of the Fijian sociopolitical class.

\section{BIBLIOGRAPHY}

Bayliss-Smith Tim, Richard Bedford, Harold Brookfield and Marc LATHAM, 1988. Islands, Islanders and the World: The Colonial and Post-colonial Experience of eastern Fiji, Cambridge.

Brown Stanley, 1973. Men from Under the Sky: The Arrival of Westerners in Fiji, Vermont and Tokyo, C.E. Tuttle Company, Ins, of Rutland.

Calvert James, 2003 ( $1^{\text {st }}$ ed. 1858). Fiji and the Fijians, vol. II : Mission History, Suva, Fiji Museum.

Campbell Ian, 1980. The Historiography of Charles Savage, Journal of the Polynesian Society 89, 2, pp. 143-166.

-, 1998. Gone Native in Polynesia: Captivity Narratives and Experiences from the South Pacific, Westport (Connecticut), Greenwood Press.

Clammer John, 1976. Literacy and Social Change: A Case Study of Fiji, Leiden, Brill.

Fison Lorimer, 1903. Land tenure in Fiji: a lecture delivered at Levuka when the Lands Commission was about to sit, Suva, Government Printer (E. J. March).

France Peter, 1969. The Charter of the Land. Custom and Colonization in Fiji, Melbourne, Oxford University Press.

Geraghty Paul, 2003. Foreigner Talk to Exonorm. Translation and Literacy in Fiji, in Sabine Fenton (ed.), For Better or Worse. Translation as a Tool for Change in the South Pacific, New York, Routledge, pp. 171-206. 
Hocart Arthur Maurice, 1913a. On the Meaning of the Fijian word Turaga, Man 13, pp. 140143.

-, 1913B. Fijian Heralds and Envoys, Journal of the Royal Anthropological Institute 43, pp. 109118.

—, 1915. Chieftainship and the Sister's Son in the Pacific, American Anthropologist 17, pp. 631-646.

-, 1929. Lau Islands, Fiji, Honolulu, Bernice P. Bishop Museum.

-, 1936 (1970). Kings and Councillors: an Essai in the Comparative Anatomy of Human Society, Chicago, University of Chicago Press.

—, 1952. Northern States of Fiji, Occasional Paper of the Royal Anthropological Institute 11.

Hooper Steven, 1996. Who Are the Chiefs? Chiefship in Lau Eastern Fiji, in R. Feinberg, R. Firth \& K. Watson-Gegeo (eds), Leadership and Change in the Western Pacific, Londres, Athlone Press, pp. 239-271.

Howard Michael, 1991. Fiji. Race and Politics in an Island State, Vancouver, UBC Press.

Geddes William, 1945. Deuba. A Study of a Fijian Village, Suva, University of the South Pacific, Institute of Pacific Studies, IPS Reprint Series.

Lyтн Richard, 1848-50. Journal, Sydney, Mitchell Library, Mf. B536-1.

—, 1836-42. Journal, Sydney, Mitchell Library, Mf. B533.

- , s.d. Tongan and Fijian reminiscences, Sydney, Mitchell Library, Mf. B549.

Maude Harry, 1964. Beachcombers and Castaways, Journal of the Polynesian Society 73, 3, pp. 254-293.

NayaCaKalou Rusiate, 1975. Leadership in Fiji, Suva and Melbourne, University of the South Pacific, Oxford University Press.
Ravuvu Asesela, 1983. Vaka i Taukei: the Fijian way of life, Suva, University of the South Pacific

Reid A.C., 1990. Tovata I \& II, Suva, Fiji Museum.

Rотн George, 1953. Fijian Way of Life, Melbourne, Oxford University Press.

Routledge David, 1985. Matanitu: the Struggle for Power in early Fiji, Suva, University of the South Pacific.

Ryle Jacqueline, 2010. My God, my land: interwoven paths of Christianity and tradition in Fiji, England, Ashgate Publishing Limited.

SaHLIns Marshall, 1981. The Stranger-king, or Dumézil among the Fijians, Journal of Pacific History 16, 3, pp. 107-132.

Samson Jane, 1998. Imperial Benevolence: Making British Authority in the Pacific Islands, Honolulu, University of Hawai'i Press.

SCARr Deryck, 1984. Fiji: a Short History, Sydney, Allen \& Unwin.

Spurway John, 2015. Ma'afu, Prince of Tonga, Chief of Fiji. The Life and Times of Fiji's first Tui Lau, Canberra, Australian National University Press.

Thornley Andrew, 2002 Exodus of the I Taukei: The Wesleyan Church in Fiji, 1848-74, Suva, Institute of Pacific Studies (USP).

Toganivalu Deve, s.d. An Island Kingdom: The history and customs of the Bawans, and their influence on Fijian Society and Government, Suva, National Archives of Fiji.

Waterhouse Joseph, 1997 (1866). The King and People of Fiji, Honolulu, University of Hawai' i Press.

Thurston John, n.d. Diary and note book re Cession of Fiji 1874, Thurston Papers.

Williams Thomas, 1982 (1858). Fiji and the Fijians. The Islands and their inhabitants, vol. 1, Suva, Fiji Musuem Suva. 